\title{
Lupus-specific Antibodies Reveal an Altered Pattern of Somatic Mutation
}

\author{
Audrey J. Manheimer-Lory, ${ }^{*}$ Gisele Zandman-Goddard, ${ }^{*}$ Anne Davidson, ${ }^{\star \ddagger}$ Cynthia Aranow, ${ }^{\S}$ and Betty Diamond ${ }^{\star \star}$ \\ $*$ Department of Microbiology and Immunology, and ${ }^{\ddagger}$ Department of Medicine, Albert Einstein College of Medicine, Bronx, New York \\ 10461; and ${ }^{\S}$ Department of Medicine, State University of New York at Downstate, Brooklyn, New York 11225
}

\begin{abstract}
The F4 idiotype is a heavy chain determinant expressed almost exclusively on IgG immunoglobulins and is highly associated with specificity for double-stranded DNA. Since high-titered F4 expression is present predominantly in sera of patients with systemic lupus erythematosus (SLE), we thought $\mathrm{F4}^{+}$IgG antibodies might constitute a useful subset of immunoglobulins in which to investigate lupus-specific alterations in variable $(\mathrm{V})$ region gene expression or in the process of somatic mutation. This molecular analysis of $\mathrm{F}^{+}$ $B$ cell lines generated from lupus patients demonstrates that despite the strong association of $\mathrm{F} 4$ reactivity with specificity for native DNA, there is no apparent $V_{H}$ gene restriction. Furthermore, $V_{H}$ gene segments encoding these antibodies are also used in protective immune responses.

An examination of the process of somatic mutation in $\mathrm{F}^{+}$ antibodies showed no abnormality in frequency of somatic mutation nor in the distribution of mutations in complementarity-determining regions or framework regions. However, there was a decrease in targeting of mutations to putative mutational hot spots. This subtle difference in mutations present in these antibodies may reflect an intrinsic defect in mutational machinery or, more likely, altered state of B cell activation that affects the mutational process and perhaps also negative selection. (J. Clin. Invest. 1997. 100:2538-2546.) Key words: autoreactivity - anti-doublestranded DNA antibody - idiotype - mutational hot spots • variable region gene expression
\end{abstract}

\section{Introduction}

Idiotypic analyses have been useful in revealing the molecular genetics of specific antibody responses. In particular, idiotypic analyses of anti-DNA antibodies have helped reveal the structural and genetic heterogeneity that characterizes this pathogenic autospecificity. Data from several laboratories demonstrate that most idiotypic specificities present on anti-DNA antibodies are also present on normal serum Igs (1). This observation implies the existence of a structural and genetic relationship between autoantibodies and antibodies that are pre-

Address correspondence to Betty Diamond, M.D., Department of Microbiology and Immunology, Albert Einstein College of Medicine, 1300 Morris Park Avenue, Bronx, NY 10461. Phone: 718-430-4081; FAX: 718-430-8711; E-mail: diamond@aecom.yu.edu

Received for publication 31 March 1997 and accepted in revised form 11 September 1997.

J. Clin. Invest.

(C) The American Society for Clinical Investigation, Inc. 0021-9738/97/11/2538/09 \$2.00

Volume 100, Number 10, November 1997, 2538-2546

http://www.jci.org sumably part of a protective immune response. However, a few idiotypes are highly restricted to DNA-binding antibodies and to individuals with $\operatorname{SLE}(2,3)$. Analysis of the molecular genetics of these idiotypes may provide clues to SLE-specific Ig expression.

We have identified three lupus-associated anti-DNA idiotypes. 3I and 8.12 are expressed in high titer in lupus sera, yet are also present on antipneumococcal antibodies from nonautoimmune individuals $(4,5)$. The $3 \mathrm{I}$ idiotype is present on $\kappa$ light chains, primarily those encoded by variable $(\mathrm{V})^{1}$ region $\kappa I$ genes (6), while the 8.12 idiotype is encoded exclusively by V $\lambda$ II light chain genes (7). Both idiotypic determinants can be encoded by germ line genes without somatic mutation, although all anti-DNA antibodies expressing these idiotypes display evidence of somatic mutation. We have interpreted these observations to mean that $3 \mathrm{I}^{+}$and $8.12^{+}$antibodies can be generated routinely in response to bacterial antigens; specificity for DNA in these idiotypic systems may be generated somatically, and a defect in the regulation of autoreactive B cells in individuals with SLE may permit the survival of cells acquiring anti-DNA specificity.

The F4 idiotype is an anti-DNA-associated idiotype that is not present in the repertoire of nonautoimmune individuals or on antipneumococcal antibodies. It is present in high titer in $\sim 50 \%$ of lupus patients with anti-double-stranded (ds) DNA activity, and from 30 to $50 \%$ of anti-DNA antibodies are F4 reactive (3). The F4 determinant is present on the heavy chain variable region, and is expressed almost exclusively on IgG antibodies (3). These observations have led us to suggest that both the F4 idiotype and DNA binding are acquired by somatic mutation, and that the F4 idiotype is intimately related to DNA specificity. As high-titered expression of this idiotype is present in SLE, a molecular genetic characterization of $\mathrm{F}^{+}$ antibodies might reveal differences in Ig variable region gene expression or in the process of somatic mutation in lupus patients that might predispose them to autoantibody production.

In this study, we characterize $10 \mathrm{~F}^{+} \mathrm{mAbs}, 8$ of which are novel, and 2 of which have been reported previously (6). The molecular genetic analysis of these antibodies confirms previous serologic studies, demonstrating a strong association of the F4 idiotype with IgG isotype and with DNA binding. F4 heavy chains are encoded by $\mathrm{V}_{\mathrm{H}}$ genes that are used in protective antibody responses. A comparison of somatic mutation in these antibodies and in antibodies from nonautoimmune individuals encoded by the same $V_{H}$ genes shows a subtle alteration in the pattern of mutation in SLE antibodies. Somatic mutation in the SLE $V_{\mathrm{H}}$ gene is targeted to a lesser extent to known mutational hot spots, suggesting an intrinsic B cell defect or an alteration in B cell activation in SLE.

1. Abbreviations used in this paper: CDR, complementarity-determining region; ds, double-stranded; FR, framework region; R, replacement; S, silent; Sm, Smith antigen; V, variable (region); $\mathrm{V}_{\mathrm{H}}$, heavy chain variable region; $\mathrm{V}_{\mathrm{L}}$, light chain variable region. 
Table I. F4 ${ }^{+}$EBV-transformed Cell Lines

\begin{tabular}{lccccccc}
\hline Patient & Line & Isotype & $3 \mathrm{I}$ & $\mathrm{V}_{\mathrm{H}}$ & $\mathrm{J}_{\mathrm{H}}$ & $\mathrm{V}_{\mathrm{L}}$ & $\mathrm{J}_{\mathrm{L}}$ \\
\hline $\mathrm{A}^{*}$ & 78 & $\gamma, \kappa$ & + & 3 & 5 & $\kappa 2$ & 2 \\
$\mathrm{~B}^{\ddagger}$ & $5-3$ & $\gamma, \kappa$ & + & 3 & 4 & $\kappa 3$ & 1 \\
$\mathrm{~B}^{\ddagger}$ & $12-2$ & $\gamma, \kappa$ & + & 3 & 6 & $\kappa 2$ & 4 \\
$\mathrm{~B}^{\ddagger}$ & $17-3$ & $\gamma, \lambda$ & - & 3 & 4 & $\lambda 3$ & $\lambda 2 / 3$ \\
$\mathrm{H}^{\S}$ & 17 & $\gamma, \lambda$ & - & 3 & 4 & $\lambda 3$ & $\lambda 2 / 3$ \\
$\mathrm{M}^{*}$ & 36 & $\gamma, \kappa$ & + & 1 & 3 & $\kappa 1$ & 2 \\
$\mathrm{MC}^{\|}$ & 90 & $\gamma, \kappa$ & + & 3 & 4 & $\kappa 1$ & 2 \\
$\mathrm{O}^{*}$ & 50 & $\gamma, \lambda$ & - & 4 & 3 & $\lambda 3$ & $\lambda 2 / 3$ \\
$\mathrm{D}^{\mathbb{T}}$ & $\mathrm{I}-2 \mathrm{a}$ & $\gamma, \kappa$ & + & 3 & 4 & $\kappa 1$ & 4 \\
$\mathrm{H}^{* \ddagger}$ & $\mathrm{H} 2 \mathrm{~F}$ & $\gamma, \kappa$ & + & 3 & 4 & $\kappa 4$ & 1 \\
& & & & & & & \\
\hline
\end{tabular}

Characteristics of $\mathrm{F}^{+}{ }^{+} \mathrm{EBV}$ lines denoting patient origin, isotype, 3I reactivity, and $\mathrm{V}_{\mathrm{H}} \mathrm{J}_{\mathrm{H}}$ and $\mathrm{V}_{\mathrm{L}} \mathrm{J}_{\mathrm{L}}$ usage. Patient clinical status at time of blood drawing: *renal disease; ${ }^{*}$ arthritis; ${ }^{\circledR}$ sample was obtained 4 yr later than $\mathrm{H} 2 \mathrm{~F}$, when patient had only arthritis; "asymptomatic; "thrombocytopenia.

\section{Methods}

\section{Generation of $\mathrm{F}^{+} \mathrm{B}$ cell clones}

Peripheral blood from six individuals (designated A, B, H, M, MC, and $\mathrm{O}$ ) with SLE (as defined by the American College of Rheumatology criteria) was obtained by venepuncture. At the time of blood collection, patients $\mathrm{A}, \mathrm{O}$, and $\mathrm{M}$ had active renal disease, $\mathrm{B}$ and $\mathrm{H}$ had arthritis only, and MC had no clinical symptomatology. All patients but $\mathrm{O}$ had a history of elevated anti-DNA titers. Four patients, B, H, $\mathrm{M}$, and $\mathrm{MC}$, also had elevated $\mathrm{F} 4$ reactivity. A seventh patient, $\mathrm{D}$, underwent splenectomy for clinical indications; therefore, splenocytes were used (6). No serum was available from this patient. Lymphocytes were obtained by Ficoll-Hypaque separation of whole blood and transformed using EBV as described previously $(6,8)$.

\section{Assays for isotype and for F4 idiotype}

Idiotypic reactivity was tested as follows. ELISA wells were coated with purified mouse $\mathrm{F} 4 \mathrm{mAb}$ at $20 \mu \mathrm{g} / \mathrm{ml}$ and incubated at $37^{\circ} \mathrm{C}$ for $1 \mathrm{~h}$. After blocking (3\% BSA in PBS), culture supernatants were added for $1 \mathrm{~h}$ at $37^{\circ} \mathrm{C}$ followed by peroxidase-conjugated goat anti-

Table II. Millipore Filter Assay for Binding to dsDNA

\begin{tabular}{lcc}
\hline Cell line & Mean \pm SD & dsDNA reactivity \\
\hline & $c p m$ & \\
A78 & $45 \pm 14.4$ & - \\
B5-3 & $86 \pm 25.2$ & - \\
B12-2 & $245 \pm 59.9$ & + \\
B17-3 & $75 \pm 21.8$ & - \\
H17 & $640 \pm 41.9$ & ++ \\
M36 & $396 \pm 36.8$ & + \\
MC90 & $410 \pm 15.2$ & + \\
050 & $3047 \pm 143.6$ & ++ \\
Human Ig & $21 \pm 0$ & - \\
& &
\end{tabular}

Supernatants from EBV cell lines $(2 \mu \mathrm{g} / \mathrm{ml})$ and human Ig $(5 \mu \mathrm{g})$ were incubated with ${ }^{32} \mathrm{P}$-labeled dsDNA and passed through a nitrocellulose filter. Reactivity is scored as follows: $-(0-100 \mathrm{cpm}),+(100-500 \mathrm{cpm})$, $++(500-1,000 \mathrm{cpm})$, and $+++(>1,000 \mathrm{cpm})$.
Table III. Comparison of Rearranged V Regions with Germ Line Genes

\begin{tabular}{lllllllll}
\hline Clone & $\mathrm{V}_{\mathrm{H}}$ & Germ line* $^{*}$ & NA $^{\ddagger}$ & AA $^{\S}$ & $\mathrm{V}_{\mathrm{L}}$ & Germ line* & NA $^{\ddagger}$ & AA $^{\S}$ \\
\hline A78 & 3 & DP35 & 93.9 & 87.8 & $\kappa 2$ & A2 & 87.6 & 83.2 \\
B5-3 & 3 & DP49 & 94.2 & 88.8 & $\kappa 3$ & A27 & 96.5 & 92.6 \\
B12-2 & 3 & DP51 & 90.1 & 86.7 & $\kappa 2$ & A2 & 86.3 & 83.2 \\
B17-3 & 3 & DP47 & 94.5 & 86.6 & $\lambda 3$ & IGLV3S2 & 96.2 & 96.5 \\
H17 & 3 & DP47 & 95.9 & 90.8 & $\lambda 3$ & III.1 & 95.3 & 94.2 \\
M36 & 1 & hv1263 & 89.5 & 82.7 & $\kappa 1$ & 08 & 96.4 & 90.5 \\
MC90 & 3 & DP58 & 96.3 & 94.9 & $\kappa 1$ & 08 & 98.0 & 96.8 \\
050\| & 4 & $71-4$ & 96.2 & 89.7 & $\lambda 3$ & hlv318 & 96.9 & 96.5 \\
I-2a $^{\text {Il }}$ & 3 & hv3005-f3 & 93.4 & 90.8 & $\kappa 1$ & L8 & 95.0 & 91.6 \\
H2F $^{\text {II }}$ & 3 & DP47 & 89.8 & 80.6 & $\kappa 4$ & B3 & 98.0 & 93.1 \\
& & & & & & & &
\end{tabular}

Summary of germ line gene usage by $\mathrm{F}^{+}$EBV-transformed lines. * References 10-13. ${ }^{*}$ Percentage of nucleic acid $(N A)$ homology. ${ }^{\S}$ Percentage of amino acid $(A A)$ homology. "Homologies for these lines only reflect sequence beginning at codon 10. "Reference 4.

human IgG/IgM/IgA (Organon Teknika-Cappel, West Chester, PA). ABTS peroxidase substrate was added (Kirkegaard \& Perry Laboratories, Inc., Gaithersburg, MD). The OD was read at $405 \mathrm{~nm}$ on an automated ELISA reader. 3I and 8.12 reactivity were analyzed similarly, using purified 3I or 8.12 antibody adsorbed to ELISA plates.

Cells from wells containing $\mathrm{F}^{+}$antibody in the supernatant were cloned by limiting dilution as described previously (6), and retested for expression of the F4, 3I, and 8.12 idiotypes as described above.

Culture supernatants of $\mathrm{F}^{+}$clones were tested for the presence of human $\kappa$ or $\lambda$ and $\mu, \gamma$, or $\alpha$ chains in a standard ELISA. Briefly, polyclonal goat anti-human $\operatorname{IgM} / \operatorname{IgG} / \operatorname{IgA}$ (heavy and light) antibody (Southern Biotechnology Associates, Inc., Birmingham, AL) was adsorbed to ELISA plates (Falcon 3915; Becton Dickinson Labware, Lincoln Park, NJ) for $1 \mathrm{~h}$ at $37^{\circ} \mathrm{C}$. After blocking, culture supernatants were added for $1 \mathrm{~h}$ at $37^{\circ} \mathrm{C}$, followed by peroxidase-conjugated goat anti-human $\operatorname{IgM} / \operatorname{IgA} / \operatorname{IgG} \kappa$ or $\lambda(1: 1,000)$ (Southern Biotechnology Associates, Inc.) for $1 \mathrm{~h}$ at $37^{\circ} \mathrm{C}$. ABTS peroxidase substrate was added, and the OD was read at $405 \mathrm{~nm}$ using an ELISA reader (Titertek Multiscan Plus; Ealabs, Finland).

\section{Antigen specificity}

dsDNA binding assay. Binding to dsDNA was determined by Millipore filter assay (Millipore Corp., Bedford, MA) (6). Briefly, supernatants were normalized for Ig concentration and tested for binding to plasmid dsDNA using nick-translated ${ }^{32} \mathrm{P}$-labeled DNA made double-stranded previously by passage through a nitrocellulose filter (HAWP 45; Millipore Corp.). Supernatants were not tested for single-stranded DNA binding.

Reactivity to Smith antigen (Sm), cardiolipin, and pneumococcal polysaccharide. Direct ELISAs were performed to test for other autoantigenic specificities according to a modified protocol from Swanson et al. (9). Briefly, wells were coated with $\mathrm{Sm}(10 \mu \mathrm{g} / \mathrm{ml})$ overnight at $4^{\circ} \mathrm{C}$. Supernatants $(5 \mu \mathrm{g} / \mathrm{ml})$ were added for $45 \mathrm{~min}$ at $25^{\circ} \mathrm{C}$. Bound samples were detected with a goat anti-human Ig (heavy and light) alkaline phosphatase-labeled conjugate (Southern Biotechnology Associates, Inc.) and developed using 104 substrate (Sigma Chemical Co., St. Louis, MO). Binding of cardiolipin (Fluka Chemical Co., Ronkonkoma, NY) was tested by adsorbing cardiolipin, $50 \mu \mathrm{g} / \mathrm{ml}$ in ethanol, to Immulon II microtiter plates overnight (Dynatech Laboratories, Inc., Chantilly, VA). Samples were added for $2 \mathrm{~h}$ at $25^{\circ} \mathrm{C}$, and bound antibody was detected as described above.

To assay binding to pneumococcal polysaccharide, $4 \mu \mathrm{g}$ Pneu$\operatorname{movax}^{\circledR} 23$ (Merck Sharp and Dohme, West Point, PA) was coated 
A

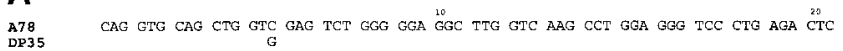

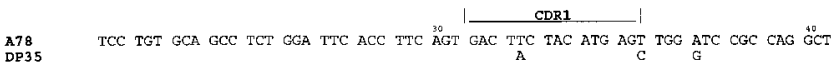

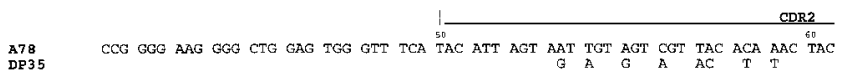

A78
D235

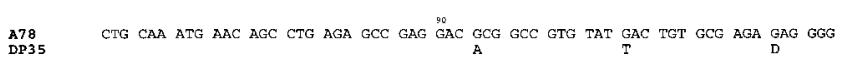

A78
DP35

A78

CCC TGG GGC CAG GGA ACC CTE GTC ACC GTC TCC TCA

BS-3
DP49

CAG GTG CAG CTG GTG GAG TCT GGG GGA GGC GTG GTC CAG CCT GGG AAG TCC CTG AGA ${ }_{G}^{20}$

B5-3
DE49

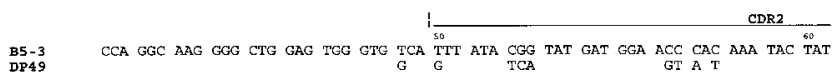

B5-3
DP49

B5 -3
DP49

B5-3 CCA GCT GGT ACT GGG AGC TTT GAC TCC TGG GGC CAG GGR ACC CTG GTC B12-2 GAG GTG CTT CTG GTG GAG TCT GGG GGA GGC CTG GTC AAG CCT GGG GGG TCC CTG AGA CTC
DP51

B12-2
DP51 TCC TGT GCC GCC TCT GGA TTC ATC TTA ÅGT AGT TAT AGC ATG AAC TGG GTC CGC CAG

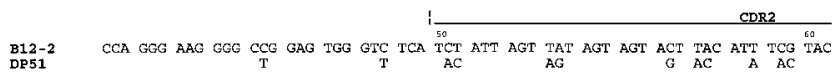

B12-2
De51

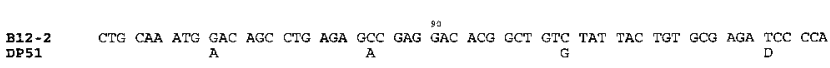

B12-2 CrT tGC aCt taC GAC TGC CAC $\mathrm{J}_{\mathrm{H}}^{6}$
De51

B12-2 ACC GTC TCC TCA

B17.3 Gag GTG CAG CTG TTA GAG TCT GGG GGA GGC TTG GTA CAG CCT GGG GGG TCC CTG AGA CTC
DP47

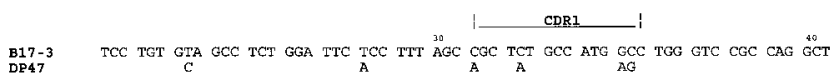

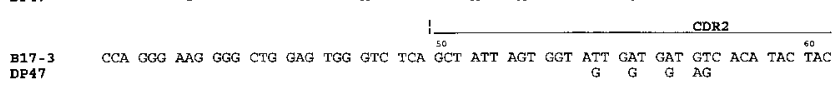

B17-3
DP47 $\underset{A}{G C A}$ GGC TCC GTG AAG GGC CGG TTC ACC ATC TCC AGA GAC AAT TCC AAG AGC ACG TTG TAT

B17-3 CTG CAA ATG AAC AGC CTG AGA GCC GAG GAC ACG GCC CTA TAT TAC TGT GCG AGG GAT TCT
DP47

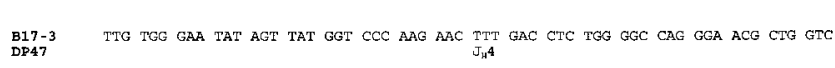

B17-3 ACC

on ELISA immunoadsorbant assay/RIA high-binding plates (Costar Corp., Cambridge, MA) overnight at $4^{\circ} \mathrm{C}$. After washing with PBSTween $(0.05 \%)$ and blocking (3\% BSA in PBS), supernatants were added for $1 \mathrm{~h}$ at $37^{\circ} \mathrm{C}$, and the assay proceeded as described above.
CAG GTG CAG CTG CAG GAG TCG GGC CCA GGA CTG GTG AAG CCT TCG GAG ACC CTG TCC C̈TC

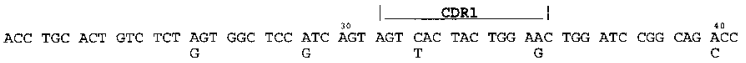
CCA GGG AAG GGG CTG GAA TGG ATT GGG ADT ATC TAT TAC AGT GGG AGC ACC AAC TAC CEC TCC CTC AAG AGT CGA GTC ACC ATA TO TCA GTA GAC ACG TCC AAG AAG CAG TTC TCC CTG AAG GTG AGC TCT GTG ACC TCT GCG GRC ACG GCC GTG TAT TAC TGT GCG AGA GAG GCA GCA GCT GGT TAT GAT GCT TTt Gat ATC TGG GGC CAA GGG ACA ATG GTC ACC GTC TCT TCA

\section{Total RNA preparation}

Total RNA was prepared from cell lines using guanidinium thiocyanate (6) or the Snap-O-Sol nucleic acid preparation kit (Biotecx Laboratories, Houston, TX). Northern blot analysis (6) was used to verify 
B

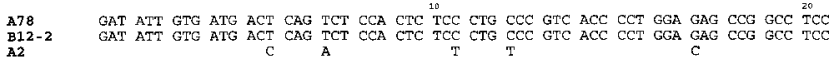

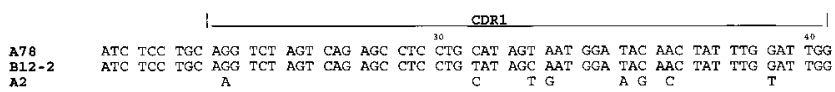

50 $1 \operatorname{CDR2}_{{ }^{60}}^{\operatorname{CD}^{\circ}}$

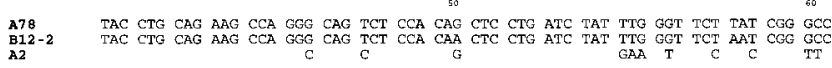
$-1$

$\begin{array}{lll}\text { A78 } & \text { TCC GGG GTC CCT GAC AGG TTC AGT GGC AOT GGA TCA GGC ACA GAT TPTP ACA CTG ATA A } \\ \text { B12-2 } & \text { ATC } \\ \text { A2 } & \text { TCGG GTC CCT GAC AGG TTC AGT GGC AGT GGA TCA GGC ACA GAT TTC ACA CTS AAA ATC }\end{array}$

A78 AGC AGA GTG GAG GCT GAG GAT GTT GGC GETT TAT TAC TGC ATG CAA GCT CTA CAA ACC CCO

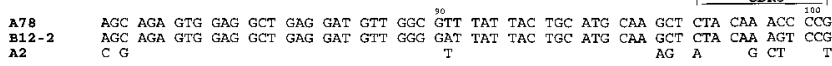

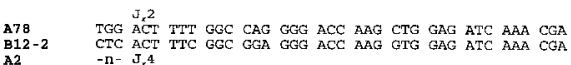

B5-3

B5-3
A27

B5-3
A27

${ }_{\text {A27 }}^{\text {B2 } 3}$

B5-3
A27

B5-3

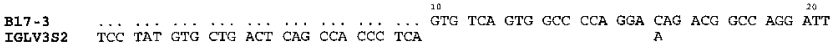

B17-3 ACC TGT GGG GGA AAC AAC ATT GGA AGC AAA AGT GTG CAT TGG TAC CAG CAG AAG CCA GGC
IGLV352

B17-3
IGLVIS2 CAG GCC CCT GTA CTG GTC GTC TAT GAT GAT AGC GAC CEG CCC TCA GGG ATC CCT GAG CGA

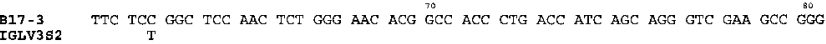

B17-3 GAT GAS GCC GAC TAT TAC TGT CAG GTG TGG GAT AGT AGT AGT GAC CCT GTG GTT TTC GGC

B17-3 GGA OGG ACC AAG CTG ACC GTC

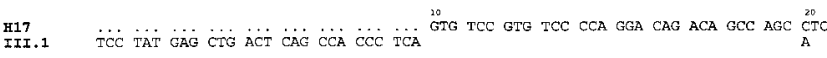

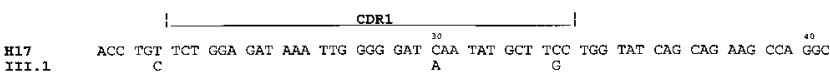

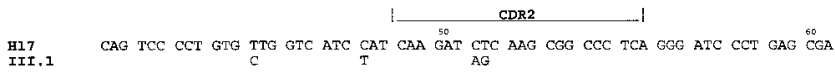

H17 TTC TCT GGC TCC AAC TCT GGG AAC ACA GCC ACT CTG ACC ATC AGC GGG ACC CAG GCT

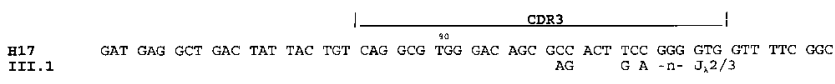

H17 GGA GGG ACC AAG CTG ACC GTC CTA

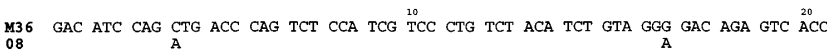
CDR1

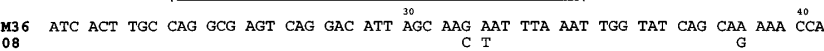

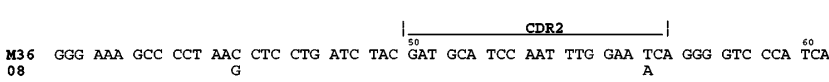
M36 AGG TTC AGT GGA AGT GGA TCT GGG ACA $\stackrel{70}{\text { GAT }}$ TTT ACT TTC ACC ATC AGC AGC CTG CAG $\stackrel{80}{\circ}$

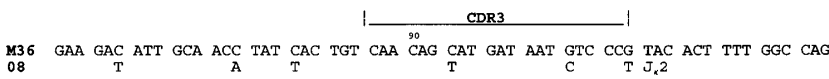
M36 GGG ACC AAG CTG GAG ATC AAA CGA

MC90 GAC ATC CAG ATG ACC CAG TCT CCA TCC TCC CTG TCT GCA TCT GTA GGA GAC AGA GTC ACC

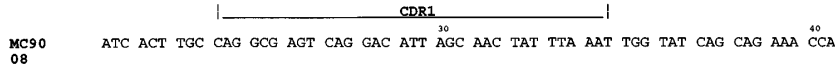

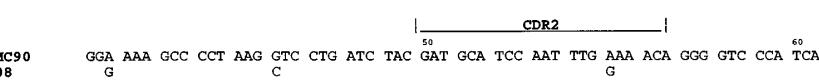
MC90 AGG TTC AAT GGA AGT GGA TCT GGG ACA GAT TTT ACT TTC ACC ATC AGC AGC CTG CAG CCT

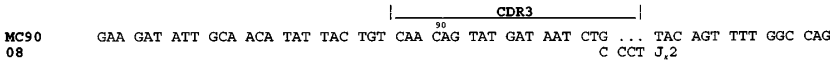
MC90 GGG ACC AAG CTG GAG ATC AAA CGA

${ }_{\text {hlv318 }}^{050}$ TCC TAT GTG CTE ACT CAG CCA CCC TCG GTG CA

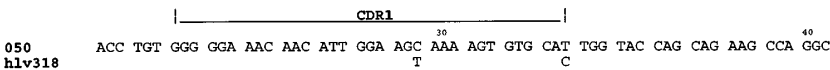
050
h1v318 CAG GCC CCT GTA CTG GTC GTC TAT GAT GAT AGC GAC GGG CCC TCA GGG ATC CCT GAG CGA 050
h1v318 TTC TCC GGC TCC AAC TCT GGG AAC ACG GCC ACC CTG ACC ATC AGC AGG GTC GAA GCC GGC 050
hlv318 GAT GAG GCC GAC TAT TAC TGT CAG GTG TGG GAT AGT AGT AGT $\underset{T}{\text { GAC }}$ ACT

050 GGA GGG ACC AAG CTG ACC GTC CTA

Figure 1. (A) Nucleotide sequences of heavy chains of $\mathrm{F}^{+}$antibodies compared with germ line genes. These sequence data are available from EMBL/GenBank Data Libraries under accession numbers U95234 (A78), U95235 (B5-3), U95238 (B12-2), U95236 (B17-3), U95237 (H17), U95239 (M36), U95240 (MC90), and U95241 (050). (B) Nucleotide sequences of light chains of $\mathrm{F}^{+}$antibodies compared with germ line genes. These sequence data are available from EMBL/GenBank Data Libraries under accession numbers U95242 (A78), U95243 (B5-3), U95244 (B12-2), U95248 (B17-3), U95249 (H17), U95245 (M36), U95246 (MC90), and U95247 (050). 
heavy chain isotype and variable region gene family using $\mathrm{C} \mu\left(5^{\prime}\right.$ GAGGGGGAAAAGGGTTGGGGC-3') and $\mathrm{C} \gamma$ (5'-GCCAGGGGGAAGACCGATGG-3') oligonucleotides and genomic DNA probes representing heavy $\left(\mathrm{V}_{\mathrm{H}}\right)$ and light $\left(\mathrm{V}_{\mathrm{L}}\right)$ chain variable gene families (6).

\section{Sequence of heavy and light chain $V$ region genes}

$5 \mu \mathrm{g}$ total RNA was reverse-transcribed using a $\mathrm{C} \gamma$ oligomer and $\mathrm{Su}-$ perscript ${ }^{\circledR}$ II RNase H reverse transcriptase (GIBCO BRL, Gaithersburg, MD). Heavy chain variable region sequences were amplified with Vent polymerase (New England Biolabs Inc., Beverly, MA) by PCR using the appropriate $3^{\prime}$ constant region oligomer in conjunction with $5^{\prime}$ leader oligomers for $\mathrm{V}_{\mathrm{H}} 1$ (5'-ATGGACTGGACCTGGCAGGAGTC-3'), $\mathrm{V}_{\mathrm{H}} 3$ (5'-ATGGAGTTTGGGCTGAGCTGG-3'), or $\mathrm{V}_{\mathrm{H}} 4$ (5'-ATGAAACACCTGTGGTTCTTC-3'). PCR DNA products were recovered by the Spin Bind PCR purification system (FMC BioProducts, Rockland, ME). Light chains were amplified similarly using a universal $\mathrm{C} \lambda$ (5'-AGTGTGGCCTTGTTGGCTTG-3') or J $\lambda$ 2/3 (5'-TAGGACGGTCAGCTTGGTCCCTCCGCCGAAAACCAC-3') or a $\mathrm{C}^{\prime}\left(5^{\prime}\right.$-GTTCCAGATTTCAACTGCTC-3') oligomer and either $5^{\prime}$ leader oligomers for $\mathrm{V}_{\mathrm{k}} \mathrm{I}$ (5'-CATGAGGGTCCCCGCTCAG-3'), $\mathrm{V}_{\mathrm{k}}$ II (5'-ATGAGGCTCCCTGCTCAGCTC-3'), or $\mathrm{V}_{\mathrm{k}}$ III (5'-ATGGAAACCCCAGCGCAGCT-3'), or a $5^{\prime}$ framework region (FR) 1 V $\lambda 3$ (5'-TCTGTGGAGCTCCAGCCGCCCTCAGTG-3') oligomer.

PCR products were cloned into the TA cloning vector $\mathrm{pCR}^{\circledR} \mathrm{II}$ (Invitrogen Corp., San Diego, CA), while $\mathrm{C} \lambda$ products were cloned into pBluescript II or pCR script vectors (Stratagene Inc., La Jolla, CA). All were sequenced using Sequenase version 2 (USB Biologicals, Cleveland, $\mathrm{OH}$ ). The University of Wisconsin Genetics Computer Group was used to analyze amino acid sequences as well as to compute isoelectric points. The predicted replacement $(\mathrm{R})$ to silent (S) mutation ratios were determined by a computer-generated program (rsanal) developed by Joseph Mindell, Daniel Lustgarten, and Elahna Paul (Albert Einstein College of Medicine). This program analyzes the likelihood that point mutation of each nucleotide in the $\mathrm{V}$ region will lead to an $\mathrm{R}$ or $\mathrm{S}$ substitution. Therefore, each nucleotide is hypothetically changed to each of the other three nucleotides, and the cumulative $\mathrm{R} / \mathrm{S}$ ratio is determined.

\section{Statistics}

RGYW $(\mathrm{R}=\mathrm{A} / \mathrm{G}, \mathrm{Y}=\mathrm{T} / \mathrm{C}, \mathrm{W}=\mathrm{A} / \mathrm{T})$ or trinucleotide hot spots were identified using a computer-generated program. The targeting of silent mutations to hot spots was determined using $2 \times 2$ contingency tables (Statview computer program). $P$ values are given for Pearson's $\chi^{2}$ analysis.

\section{Results}

Generation and characterization of $\mathrm{F}^{+}$lines. Sera from six lupus patients were titered for dsDNA reactivity. High-titered dsDNA reactivity (greater than the mean of control sera +2SD) was observed for patients A, B, H, M, and MC (data not shown), but not for patient O. Similarly, elevated levels of F4 were observed in sera from all patients except patients $\mathrm{O}$ and $\mathrm{H}$ (data not shown). Peripheral blood lymphocytes from these patients were transformed with EBV and cloned at 1 wk, before screening for idiotype expression. In addition, splenocytes from patient D were transformed by EBV. No simultaneous serum was available for idiotypic analysis. Approximately 100 clones from each patient were screened. 21 independent idiotype-positive clones were identified, and 8 of these were maintained successfully in culture. The characteristics of these eight clones as well as two $\mathrm{F}^{+}$antibodies (I-2a and $\mathrm{H} 2 \mathrm{~F}$ ) described previously are shown in Table I. All antibodies express an $\mathrm{IgG}_{1}$ heavy chain (data not shown). This is consistent with previous studies of myeloma proteins and serum $\mathrm{Ig}$ showing that $\mathrm{F}^{+}{ }^{+}$Igs are almost exclusively $\operatorname{IgG}(3)$. Seven lines express a $\kappa$ light chain, all of which are $3 \mathrm{I}^{+}$, confirming the preferential association of $\mathrm{F}^{+}$heavy chains with $3 \mathrm{I}^{+}$light chains (3). Three lines, each derived from a different patient, express a $\lambda$ light chain, although none is $8.12^{+}$. This observation is also consistent with studies of myeloma proteins showing no association between F4 and 8.12 specificities.

$\mathrm{F}^{+}{ }^{+}$antibodies were tested for binding to dsDNA and a panel of SLE autoantigens with which anti-DNA antibodies may cross-react. Five of the eight novel $\mathrm{F}^{+}$antibodies as well as the two antibodies reported previously (6) bound dsDNA, confirming the strong association of F4 reactivity with native DNA (Table II). None bound Sm or cardiolipin (data not shown). The antibodies were also tested for binding to pneumococcal polysaccharide, since we had shown previously that antibodies expressing anti-DNA-associated idiotypes may bind pneumococcal antigen. None was reactive to pneumococcal polysaccharide by ELISA (data not shown).

$V$ gene usage in $\mathrm{F}^{+}$antibodies. Of the $10 \mathrm{~F}^{+}$antibodies, 8 have heavy chains encoded by members of the $\mathrm{V}_{\mathrm{H}} 3$ gene family, with 3 of these deriving from the DP47 germ line gene. One antibody is encoded by a member of the $\mathrm{V}_{\mathrm{H}} 1$ gene family, and another is encoded by a gene from the $\mathrm{V}_{\mathrm{H}} 4$ family (Table III) (10-13). All $V_{H}$ genes have been reported to be expressed in non-DNA-binding antibodies from nonautoimmune individuals. Nucleotide sequences of the eight novel $\mathrm{F}^{+}$variable regions are displayed in Fig. $1 A$.

7 of the 10 light chains are encoded by $\mathrm{V} \kappa$ genes from the $\mathrm{V}_{\mathrm{K}} \mathrm{I}, \mathrm{V}_{\mathrm{K}} \mathrm{II}, \mathrm{V}_{\mathrm{K}} \mathrm{III}$, and $\mathrm{V}_{\mathrm{K}} \mathrm{IV}$ families. The three antibodies expressing $\lambda$ light chains all use $\mathrm{V} \lambda 3$ genes. Nucleotide sequences of novel $\mathrm{F}^{+}$light chains are shown in Fig. $1 \mathrm{~B}$. A FASTA computer search was used to identify the germ line genes most homologous to the genes encoding the expressed $\mathrm{F}^{+}$lupus antibodies. Nucleic and amino acid homologies to putative germ line genes are presented in Table III.

Protein sequences of $\mathrm{F}^{+}$antibodies shown in Figs. 2 and 3 were compared to the protein sequences encoded by the putative germ line genes. Arginines in complementarity-determining region (CDR) 3 of the heavy chain have been suggested to be an important structural motif of murine DNA-binding antibodies (14). In addition, asparagine, lysine, and glutamine have been implicated in DNA binding (15). While there was a notable absence of arginines in CDR3 of $\mathrm{F}^{+}$heavy chains, arginine, asparagine, and charged residues were present frequently in CDR1 and CDR2, often representing an amino acid substitution from the germ line encoded sequence.

Since nephritogenic antibodies are often cationic (16-18), it was of interest to determine the isoelectric points of the heavy and light chain variable region sequences. Most F4 reactive heavy chains are cationic; only two are not, and these two derive from non-DNA-binding antibodies (Table IV). In general, the germ line encoded sequence is strongly cationic, and mutation is not required to generate the charge of the heavy or light chain variable region.

Mutational analysis. Extensive somatic mutation is apparent in many of the heavy chain $\mathrm{V}$ region sequences (Fig. 1 $A$ ), consistent with, although not proving, the hypothesis that mutation is necessary for expression of the F4 idiotype. All light chain $\mathrm{V}$ region genes are also mutated somatically (Fig. $1 B$ ). Since the heavy chains express the SLE-specific F4 idiotype, these were analyzed extensively to see if they might provide 


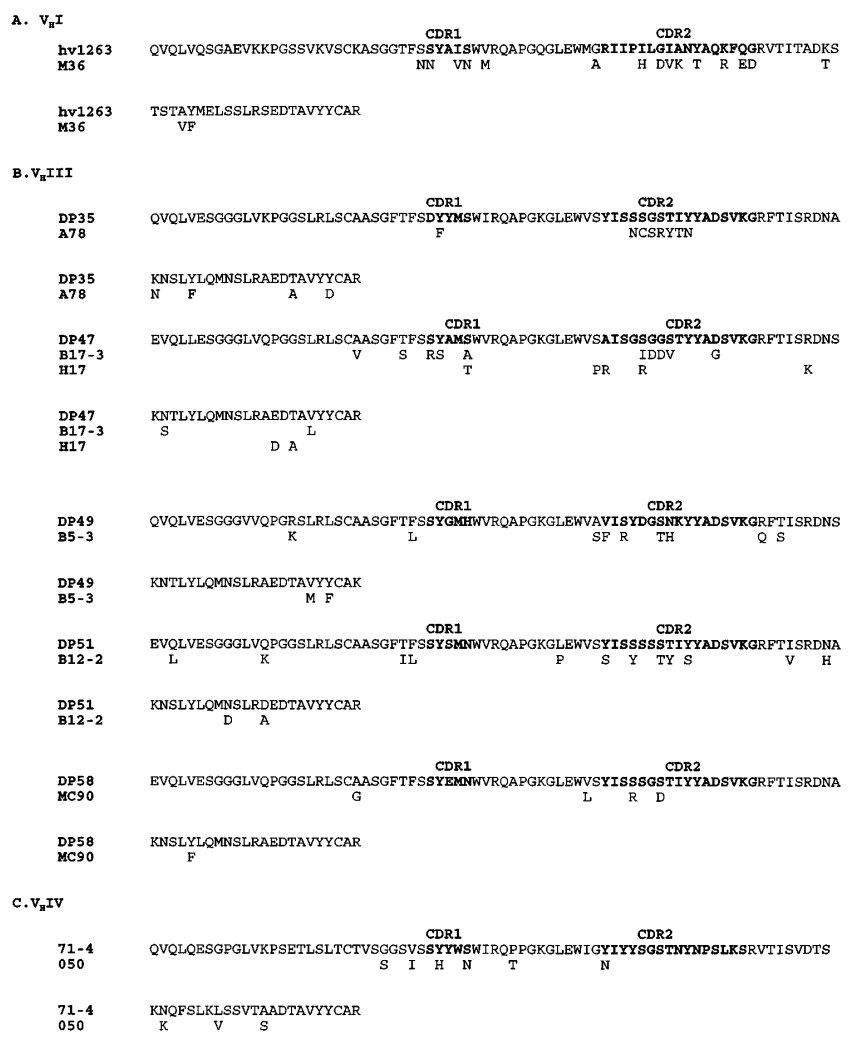

Figure 2. The deduced protein sequences of heavy chains of $\mathrm{F}^{+}$antibodies compared with translated germ line genes.

evidence of lupus-specific mutational processes. The R/S mutation ratios were computed over the FRs and CDRs for each variable region (Table $\mathrm{V}$ ). Clustering of $\mathrm{R}$ mutations in CDRs and a higher than random $\mathrm{R} / \mathrm{S}$ ratio in CDRs are both considered evidence of antigen selection. $\mathrm{R}$ mutations were clustered in CDRs of $\mathrm{F}^{+}$antibodies; $70 \%$ of all $\mathrm{R}$ mutations were in CDRs. While the R/S ratios in CDR1 were lower than the predicted random ratios, $\mathrm{F}^{+}$heavy chains displayed a trend for higher than random $\mathrm{R} / \mathrm{S}$ ratios in $\mathrm{CDR} 2$.

We sought to compare the frequency of mutation in $\mathrm{F}^{+}$ heavy chain $V_{H}$ genes to that in protective antibodies encoded by the same $\mathrm{V}_{\mathrm{H}}$ genes derived from nonautoimmune individuals (Table VI) (19-29). No significant difference between the two groups was found; $\mathrm{F}^{+} \mathrm{V}_{\mathrm{H}}$ genes contained 194 mutations in 10 sequences, while 437 mutations were present in 24 sequences from nonautoimmune individuals (data not shown).

Several investigators have described mutational hot spots, which appear to be targets of hypermutation (30-32). Rogozin and Kolchanov (31) have identified sequences RGYW as potential hot spots. Recently, Smith et al. analyzed the untranslated flanking regions of $\mathrm{Ig} \mathrm{V}$ genes and concluded that four trinucleotide sequences, AGC, TAC, GCT, and GTA, appear to be dominant mutational hot spots (32). We were interested in determining whether these hot spots were targeted for mutation in SLE B cells. Therefore, we examined the frequency of mutation in hot spots (mutated/nonmutated) compared with the frequency of mutation in the rest of the gene in both SLE and non-SLE antibodies. To insure that the analysis was not confounded by altered selection in SLE, we analyzed only
S mutations, which could not be subject to pressures of selection. The data show that there is a significant targeting of mutation to RGYW hot spots in antibodies derived from nonSLE individuals. 34 of 1,164 hot spots were mutated; in contrast, only 64 of 5,979 non-hot spots were mutated $(P<$ 0.0001 , Table VII). This is in striking contrast to SLE antibodies, in which there was no significant targeting of mutation to RGYW motifs. 13 of 485 hot spots displayed S mutations, while 42 of 2,507 non-hot spots displayed S mutations $(P>$ 0.1 , Table VII). When trinucleotide hot spots were examined, there again was a significant clustering of $\mathrm{S}$ mutations in hot spot motifs in antibodies from nonautoimmune individuals $(P<0.0001$, Table VII). In SLE antibodies, targeting to trinucleotide hot spots was also evident but was less than that observed for non-SLE antibodies $(P<0.01$, Table VII $)$.

\section{Discussion}

The molecular genetic analysis of EBV-transformed $\mathrm{F}^{+}$cells confirms the results of previous studies on $\mathrm{F}^{+}$myeloma proteins and SLE sera (3). All of the $\mathrm{F}^{+}$antibodies reported here are $\mathrm{IgG}_{1}$, confirming the observation that $\mathrm{F} 4$ reactivity is highly restricted to $\mathrm{IgG}$. Second, there is a strong correlation between $\mathrm{F}^{+}$expression, cationicity, and DNA binding. In fact, our results show that all but two $\mathrm{F}^{+}$heavy chains in this study are cationic, and of the eight cationic $\mathrm{F}^{+}$heavy chains, seven bind dsDNA. Sequence analysis revealed that the germ

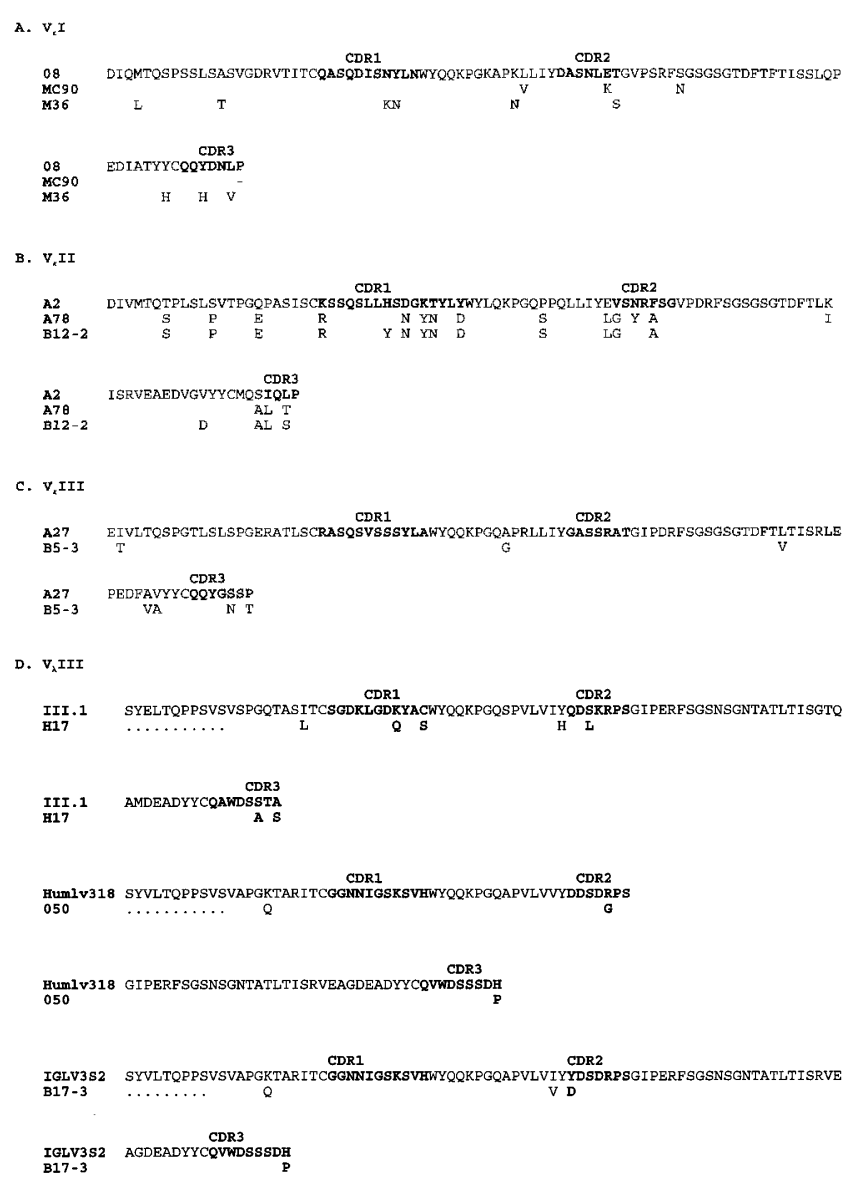

Figure 3. The deduced protein sequences of light chains of $\mathrm{F}^{+}$antibodies compared with translated germ line genes. 
Table IV. Isoelectric Points

\begin{tabular}{lcccc}
\hline Cell line & Germ line $\mathrm{V}_{\mathrm{H}}$ & Heavy chain VDJ & Germ line $\mathrm{V}_{\mathrm{L}}$ & Light chain VJ \\
\hline A78 & 9.32 & 6.48 & 7.17 & 5.81 \\
B5-3 & 9.87 & 9.31 & 6.45 & 8.66 \\
B12-2 & 8.07 & 7.79 & 7.17 & 5.04 \\
B17-3 & 8.65 & 6.52 & 5.63 & 4.41 \\
H17 & 8.65 & 9.28 & 4.36 & 4.51 \\
M36 & 10.25 & 9.34 & 3.94 & 5.65 \\
MC90 & 8.07 & 10.29 & 3.94 & 6.44 \\
050 & 9.30 & 8.08 & 4.98 & 4.41 \\
I-2a & 9.92 & 8.65 & 8.07 & 8.65 \\
H2F & 8.65 & 8.41 & 7.04 & 11.15 \\
& & & & \\
\hline
\end{tabular}

line genes used to encode $\mathrm{F}^{+}$antibodies encode cationic sequences, and that somatic mutation is not critical for their charge. Similarly, Harada et al. have found that the very cationic light chains found in anti-DNA antibodies are encoded by a $\mathrm{V}_{\mathrm{K}}$ gene which in its germ line configuration encodes a highly cationic sequence (17). Furthermore, an isolated heavy chain encoded by a $\mathrm{V}_{\mathrm{H}} 4$ variable region gene has been shown to bind dsDNA, and this heavy chain also derives from a germ line gene that is cationic (33). Antibody 050 has seven of nine CDR2 residues in common with this isolated $\mathrm{V}_{\mathrm{H}} 4$ heavy chain.

Since F4 is a lupus-associated idiotype (3) (60\% of lupus patients have elevated titers of $\mathrm{F}^{+}$Igs in their sera), it was possible that it would be encoded by a single $\mathrm{V}_{\mathrm{H}}$ gene. However, sequence analysis showed that several $\mathrm{V}_{\mathrm{H}}$ gene families can encode $\mathrm{F}^{+}$heavy chains. The fact that most of the antibodies reported here are encoded by $\mathrm{V}_{\mathrm{H}} 3$ genes probably does not reflect an idiotypic bias for $\mathrm{V}_{\mathrm{H}} 3$, but rather the predominant use of $\mathrm{V}_{\mathrm{H}} 3$ genes in human peripheral blood $\mathrm{B}$ cells (34). Furthermore, the $\mathrm{V}_{\mathrm{H}}$ genes used to encode $\mathrm{F}^{+}$antibodies are expressed in the repertoire of nonautoimmune individuals, suggesting that the F4 idiotype is generated by convergent patterns of somatic mutation and not by usage of a single $V_{H}$ gene or by an infrequently used subset of $\mathrm{V}_{\mathrm{H}}$ genes.

No cell line expresses a $\mathrm{J}_{\mathrm{H}} 1$ or $\mathrm{J}_{\mathrm{H}} 2$ gene segment. While it is tempting to speculate that the absence of $\mathrm{J}_{\mathrm{H}} 1$ and $\mathrm{J}_{\mathrm{H}} 2$ suggests

Table V. R/S Ratios in $\mathrm{F4}^{+} V_{H}$ Regions

\begin{tabular}{|c|c|c|c|c|c|c|c|c|c|c|}
\hline & \multicolumn{5}{|c|}{ Actual R/S ratio } & \multicolumn{5}{|c|}{ Predicted random rates* } \\
\hline & FR1 & CDR1 & FR2 & CDR2 & FR3 & FR1 & CDR1 & FR2 & CDR2 & FR3 \\
\hline A78 & $0: 1$ & $1: 1$ & $1: 0$ & $7: 0$ & $4: 2$ & 2.4 & 12.7 & 2.9 & 3.9 & 3.0 \\
\hline B5-3 & $2: 0$ & $0: 1$ & 1:0 & 4:0 & $4: 0$ & 2.4 & 6.2 & 2.9 & 3.4 & 3.1 \\
\hline B12-2 & $4: 3$ & $0: 1$ & $1: 1$ & $5: 2$ & $4: 1$ & 2.4 & 10.3 & 2.9 & 4.2 & 3.3 \\
\hline B17-3 & $2: 1$ & 3:0 & $0: 0$ & $5: 0$ & $3: 1$ & 2.5 & 6.2 & 2.9 & 3.1 & 3.1 \\
\hline H17 & $0: 2$ & 1:0 & 1:0 & $2: 0$ & $4: 0$ & 2.5 & 6.2 & 2.9 & 3.1 & 3.1 \\
\hline M36 & $1: 5$ & 3:0 & $2: 1$ & $8: 1$ & $3: 3$ & 2.6 & 4.4 & 3.1 & 3.2 & 3.2 \\
\hline MC90 & $1: 1$ & 1:0 & 1:0 & $2: 1$ & $1: 2$ & 2.4 & 16.0 & 2.9 & 3.9 & 3.0 \\
\hline O50 & $2: 0$ & $2: 0$ & $1: 2$ & 1:0 & $3: 0$ & 2.3 & 8.6 & 2.9 & 3.5 & 2.6 \\
\hline $\mathrm{I}-2 \mathrm{a}$ & $2: 4$ & $2: 1$ & 1:1 & $6: 1$ & $3: 4$ & 2.4 & 6.2 & 2.9 & 3.4 & 3.1 \\
\hline $\mathrm{H} 2 \mathrm{~F}$ & $2: 4$ & $2: 1$ & 1:1 & $6: 1$ & $3: 4$ & 2.5 & 6.2 & 2.9 & 3.1 & 3.1 \\
\hline
\end{tabular}

*Predicted random rate was determined by a computer-generated program (rsanal) developed by Joseph Mindell, Daniel Lustgarten, and Elahna Paul (Albert Einstein College of Medicine). that receptor editing of heavy chain genes occurs frequently in individuals with SLE, studies of 34 antibodies to foreign antigens derived from nonautoimmune individuals also show that only one anti-HIV antibody (29) and one antibody-specific Haemophilus influenzae type $\mathrm{B}(22)$ are encoded by a $\mathrm{J}_{\mathrm{H}} 1$ or $\mathrm{J}_{\mathrm{H}} 2$ segment. Previous analysis of 97 autoantibodies (35) showed that only 3 antibodies are encoded by $\mathrm{J}_{\mathrm{H}} 1$ or $\mathrm{J}_{\mathrm{H}} 2$ gene segments. The absence of these gene segments appears to be a general characteristic of the human heavy chain repertoire, perhaps due to recombination signal sequences that do not favor rearrangement. Further studies of unexpressed VDJ sequences are needed to address this question.

While $\mathrm{F}^{+}$heavy chains can associate with $\lambda$ light chains, most F4-reactive antibodies possess $\kappa$ light chains, and all of these are $3 \mathrm{I}^{+}$. This confirms a previous analysis of myeloma proteins that demonstrated a significant association of F4 and 3I reactivity. We looked for indirect evidence of receptor editing by examining whether any $V_{k}$ sequences were encoded by upstream $V_{\mathrm{K}}$ segments $\left(\mathrm{J}_{\mathrm{K}}\right.$ distal) and downstream $\mathrm{J}_{\mathrm{K}}$ segments. Three $\mathrm{F}^{+}$antibodies (A78, M36, and MC90) use upstream $\mathrm{V}_{\mathrm{k}}$ genes; however, these do not express downstream $\mathrm{J}_{\mathrm{K}}$ segments. Only the B12-2 non-DNA-binding antibody expresses a $\mathrm{J}_{K}-$ distal $V_{K}$ with a downstream $J_{\kappa}$ segment $\left(J_{K} 4\right)$. This result concurs with those of others suggesting that there is little evidence for receptor editing of light chains in these autoreactive B cells (36). Perhaps it is a lack of editing that helps predispose some individuals to the production of autoreactive B cells. In support of this argument are data showing the failure of SLE B cells to edit the A30- $\mathrm{J}_{\mathrm{K}} 2-\mathrm{C}_{\mathrm{K}}$ rearrangement, which is rarely expressed in nonautoimmune individuals but has been shown to exhibit nephritogenic potential in SLE individuals (37).

Table VI. Antibodies to Foreign Antigens

\begin{tabular}{|c|c|c|c|}
\hline Antibody & Specificity & Germ line & Reference \\
\hline M20003 & Cytomegalovirus & hv1263 & 19 \\
\hline L08086 & Rabies & hv1263 & 20 \\
\hline L08082 & Rabies & DP35 & 20 \\
\hline mAb52 & Rabies & DP35 & 20 \\
\hline L08088 & Rabies & DP47 & 20 \\
\hline L08083 & Rabies & DP47 & 20 \\
\hline L08090 & Rabies & DP47 & 20 \\
\hline $\mathrm{L} 25292$ & HIV & DP47 & 21 \\
\hline M86597 & H. influenzae type b polysaccharide & DP47 & 22 \\
\hline M86601 & H. influenzae type b polysaccharide & DP47 & 22 \\
\hline L14820 & H. influenzae type b polysaccharide & DP47 & 22 \\
\hline L14822 & H. influenzae type b polysaccharide & DP47 & 22 \\
\hline L14821 & H. influenzae type b polysaccharide & DP47 & 22 \\
\hline X56526 & H. influenzae type b polysaccharide & DP47 & 22 \\
\hline $\mathrm{U} 27189$ & Cryptococcus & DP47 & 23 \\
\hline L26898 & Cytomegalovirus & DP51 & 24 \\
\hline L04329 & Staphylococcus A & DP51 & 25 \\
\hline L26907 & Herpes & DP51 & 26 \\
\hline L38561 & HIV & DP58 & 27 \\
\hline L03824 & Staphylococcus A & DP58 & 25 \\
\hline L03825 & Staphylococcus A & DP58 & 25 \\
\hline L03677 & Hepatitis B & $71-4$ & 28 \\
\hline M67503 & HIV & $71-4$ & 29 \\
\hline L08087 & Rabies & $71-4$ & 20 \\
\hline
\end{tabular}


Table VII. Silent Mutations in Hot Spots

\begin{tabular}{lrc}
\hline \multicolumn{1}{c}{ RGYW motif } & Hot spots & Non-hot spots \\
\hline Non-SLE & & \\
$\quad$ Mutated & 34 & 64 \\
Unmutated & 1132 & 5915 \\
$\quad$ Total & 1164 & $5979(P<0.001)$ \\
SLE & & \\
$\quad$ Mutated & 13 & 42 \\
$\quad$ Unmutated & 472 & 2465 \\
Total & 485 & $2507(P>0.1)$ \\
& & \\
\hline
\end{tabular}

Trinucleotide motifs

$\begin{array}{lrc}\text { Non-SLE } & & \\ \text { Mutated } & 36 & 62 \\ \text { Unmutated } & 1425 & 5622 \\ \text { Total } & 1461 & 5684(P<0.0001) \\ \text { SLE } & & \\ \text { Mutated } & 19 & 36 \\ \text { Unmutated } & 579 & 2385 \\ \text { Total } & 598 & 2421(P<0.01)\end{array}$

$P$ values are determined by a $\chi^{2}$ analysis of S mutations in hot spots over total hot spots, compared with $\mathrm{S}$ mutations in non-hot spots over total non-hot spots. This represents the targeting of mutations to hot spot motifs.

Sequence analysis confirms the hypothesis that $\mathrm{F}^{+}$antibodies are mutated somatically. In the heavy chain variable regions, mutations in CDR2 are more prevalent than mutations in CDR1. This is consistent with other studies showing an increased frequency of somatic mutation in CDR2 of $\mathrm{V}_{\mathrm{H}} 3$ and $\mathrm{V}_{\mathrm{H}} 4$ genes encoding autoantibodies $(18,38)$. Radic and Weigert have suggested that CDR2 of the heavy chain plays an important role in DNA binding, and a large number of murine anti-DNA antibodies also display extensive mutation of CDR2 in the heavy chain $\mathrm{V}$ region (39).

Because $\mathrm{F}^{+}$antibodies are mutated, and because they are present almost uniquely in SLE serum, they offer the opportunity to study the pattern of somatic mutation in $\mathrm{V}_{\mathrm{H}}$ genes used by lupus antibodies. While other SLE-associated idiotypes like 3I and 8.12 are expressed on protective antibodies in normal serum, $\mathrm{F}^{+}$antibodies do not appear to be part of a protective response and are not present in normal serum. Therefore, we reasoned that the analysis of somatic mutation in $\mathrm{F}^{+}$heavy chains might reveal a population of $\mathrm{V}_{\mathrm{H}}$ genes displaying SLEspecific aspects of somatic mutation.

Analysis of $\mathrm{R}$ and $\mathrm{S}$ mutations displayed a clustering of $\mathrm{R}$ mutations in CDRs and a trend toward a higher than random $\mathrm{R} / \mathrm{S}$ ratio in CDRs. These observations are more consistent with antigen selection than polyclonal activation, yet it is not possible from these studies to know whether the selecting antigen is a self or foreign antigen.

Smith and colleagues reported recently no difference in use of trinucleotide mutational hot spots between autoantibodies and anti-foreign antibodies in mice (32); however, they analyzed autoantibodies derived from MRL/lpr mice. MRL/lpr mice are autoimmune due to a defect in fas gene expression (40), which would not be expected to be involved in the process of somatic mutation. Our analysis reveals the same fre- quency of mutation in $\mathrm{V}_{\mathrm{H}}$ genes encoding $\mathrm{F}^{+}$heavy chains as in these genes encoding protective antibodies. However, we do find evidence for decreased targeting of somatic mutation to mutational hot spots when RGYW motifs are examined. When trinucleotide motifs are examined, there remains a targeting of somatic mutation to hot spots, but it is less than that seen in non-lupus heavy chains. This observation suggests that mutation can be uncoupled from targeting to hot spots. We would speculate that one complex is needed for mutation to occur, and that additional proteins are needed to target mutation to particular DNA sequences.

These results are similar to other studies in our laboratory which found that germinal center B cells of mice constitutively expressing bcl-2 show no decrease in frequency of somatic mutation of Ig genes, but a decreased targeting of mutation to putative mutational hot spots (41). Recent studies have shown that expression of bcl-2 inhibits progression through the cell cycle $(42,43)$. Possibly, the alteration in cell cycle kinetics leads to a change in the process of somatic mutation. More likely, constitutive expression of bcl-2 may alter gene expression in B cells and lead to an uncoupling of mutation from targeting to hot spots. Constitutive expression of bcl-2 or other alterations in B cell activation might affect expression of proteins needed to target mutation to hot spots. While the data remain inconclusive, it has been suggested that SLE B cells overexpress bcl-2 $(44,45)$.

It is possible, given the data presented, that there is a defect in the machinery of somatic mutation in SLE B cells, but it is more likely that the altered pattern of somatic mutation reflects a difference in $\mathrm{B}$ cell activation that may determine thresholds for negative selection. Alterations in B cell gene expression might affect both the targeting of somatic mutation and thresholds for negative selection. For example, increased expression of bcl-2, reported to occur in SLE B cells (44), affects both resistance to apoptosis and the targeting of somatic mutation to hot spot motifs. Alternatively, other changes in gene expression might lead to an uncoupling of mutation from targeting to hot spots. Because our analysis of mutation focuses exclusively on $\mathrm{S}$ mutations, we can conclude that the decreased frequency of mutation in hot spots is not a function of altered selection in SLE. We would speculate that the abnormal pattern of mutation is not itself responsible for the autospecificities that are present. Rather, we believe as stated above that overexpression of bcl-2, or some other change in $\mathrm{B}$ cell activation, is responsible for both the altered mutational pattern characterized by an uncoupling of mutation from targeting to hot spots, and the altered selection of B cells. We believe that SLE B cells may undergo germinal center maturation while in a different activation state. Taken together, these data might suggest that autospecificities in SLE arise due to a lack of negative selection of B cells acquiring autoreactivity through somatic mutation, rather than an antigen-specific activation of autoreactive cells. B cells in SLE may have an altered pattern of gene expression that leads to enhanced survival and an uncoupling of mutation from hot spot targeting.

\section{Acknowledgments}

The authors wish to thank Dr. Matthew Scharff and Philip Kuo for their critical reading of the manuscript. We are grateful to Milagros Borgas and Sylvia Jones for help in the preparation of the manuscript. 
This work was supported by National Institute of Arthritis and Musculoskeletal and Skin Diseases grants AR-42481 (A. Davidson) and AR-32371 (B. Diamond).

\section{References}

1. Isenberg, D., W. Williams, J. Axford, R. Bakimer, D. Bell, T. CasasecaGrayson, B. Diamond, F. Ebling, B. Hahn, G. Harkiss, et al. 1990. Comparison of DNA antibody idiotypes in human sera: an international collaborative study of 19 idiotypes from 11 different laboratories. J. Autoimmun. 3:393-414.

2. Diamond, B., and G. Solomon. 1983. A monoclonal antibody recognizes anti-DNA antibodies in patients with systemic lupus erythematosus. Ann. NY Acad. Sci. 418:379-385.

3. Davidson, A., A. Smith, J. Katz, J.L. Preud'Homme, A. Solomon, and B. Diamond. 1989. A cross-reactive idiotype on anti-DNA antibodies defines a $\mathrm{H}$ chain determinant present almost exclusively on IgG antibodies. J. Immunol. 143:174-180

4. Grayzel, A., A. Solomon, C. Aranow, and B. Diamond. 1991. Antibodies elicited by pneumococcal antigens bear an anti-DNA-associated idiotype. $J$. Clin. Invest. 87:842-846.

5. Livneh, A., E. Gazit, and B. Diamond. 1994. The preferential expression of the anti-DNA associated 8.12 idiotype in lupus is not genetically controlled. Autoimmunity. 18:1-6.

6. Manheimer-Lory, A., J.B. Katz, M. Pillinger, C. Ghossein, A. Smith, and B. Diamond. 1991. Molecular characteristics of antibodies bearing an antiDNA-associated idiotype. J. Exp. Med. 174:1639-1652.

7. Paul, E., A. Iliev, A. Livneh, and B. Diamond. 1992. The anti-DNA-associated idiotype 8.12 is encoded by the V $\mathrm{NII}$ gene family and maps to the vicinity of L chain CDR1. J. Immunol. 149:3588-3595.

8. Davidson, A., A. Manheimer-Lory, C. Aranow, R. Peterson, N. Hannigan, and B. Diamond. 1990. Molecular characterization of a somatically mutated anti-DNA antibody bearing two systemic lupus erythematosus-related idiotypes. J. Clin. Invest. 85:1401-1409.

9. Swanson, P.C., C. Ackroyd, and G.D. Glick. 1996. Ligand recognition by anti-DNA autoantibodies. Affinity, specificity and mode of binding. Biochemistry. 35:1624-1633.

10. Tomlinson, I.M., G. Walter, J.D. Marks, M.B. Llewelyn, and G. Winter. 1992. The repertoire of human germline $V_{H}$ reveals about fifty groups of $V_{H}$ segments with different hypervariable loops. J. Mol. Biol. 227:776-798.

11. Cox, J.P.L., I.M. Tomlinson, and G. Winter. 1994. A directory of human germline $\mathrm{V}_{\mathrm{K}}$ segments reveals a strong bias in their usage. Eur. J. Immunol. 24: $827-836$

12. Daley, M.D., H.-Q. Peng, V. Misener, X.-Y. Liu, P.P. Chen, and K. Siminovitch. 1992. Molecular analysis of human immunoglobulin V $\lambda$ germline

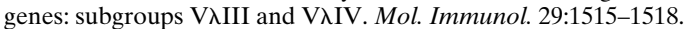

13. Williams, C., and G. Winter. 1993. Cloning and sequencing of human immunoglobulin V $\lambda$ gene segments. Eur. J. Immunol. 23:1456-1461.

14. Radic, M.Z., J. Mackle, J. Erickson, C. Mol, W.F. Anderson, and M. Weigert. 1993. Residues that mediate DNA binding of autoimmune antibodies. J. Immunol. 150:4966-4977.

15. Seeman, N.C., J.M. Rosenberg, and A. Rich. 1976. Sequence-specific recognition of double helical nucleic acids by proteins. Proc. Natl. Acad. Sci. USA. 73:804-808.

16. O'Keefe, T.L., S.K. Datta, and T. Imanishi-Kari. 1992. Cationic residues in pathogenic anti-DNA autoantibodies arise by mutations of a germ-line gene that belongs to a large $\mathrm{V}_{\mathrm{H}}$ gene subfamily. Eur. J. Immunol. 22:619-624.

17. Harada, T., N. Suzuki, Y. Mizushima, and T. Sakane. 1994. Usage of a novel class of germline Ig variable region gene for cationic anti-DNA autoantibodies in human lupus nephritis and its role for the development of the disease. J. Immunol. 153:4806-4815.

18. Demaison, C., P. Chastagner, J. Theze, and M. Zouali. 1994. Somatic diversification in the heavy chain variable region genes expressed by human autoantibodies bearing a lupus-associated nephritogenic anti-DNA idiotype. Proc. Natl. Acad. Sci. USA. 91:514-518.

19. Newkirk, M.M., H. Gram, G.F. Heinrich, L. Ostberg, J.D. Capra, and R.L. Wasserman. 1988. Complete protein sequences of the variable regions of the cloned heavy and light chains of a human anti-cytomegalovirus antibody reveal a striking similarity to human monoclonal rheumatoid factors of the Wa idiotypic family. J. Clin. Invest. 81:1511-1518.

20. Ikematsu, H., N. Harindranath, Y. Ueki, A.L. Notkins, and P. Casali. 1993. Clonal analysis of a human antibody response. II. Sequences of the $V_{H}$ genes of human IgM, IgG and IgA to rabies virus reveal a preferential utilization of $\mathrm{V}_{\mathrm{H}} \mathrm{III}$ segments and somatic hypermutation. J. Immunol. 150:1325-1337.

21. Harindranath, N., H. Ikematsu, A.L. Notkins, and P. Casali. 1993. Structure of the $\mathrm{V}_{\mathrm{H}}$ and $\mathrm{V}_{\mathrm{L}}$ segments of polyreactive and monoreactive human natural antibodies to HIV-1 and Escherichia coli $\beta$-galactosidase. Int. Immunol. 5:1523-1533

22. Adderson, E.E., P.G. Shackelford, A. Quinn, P.M. Wilson, M.W. Cun- ningham, R.A. Insel, and W.L. Carroll. 1993. Restricted immunoglobulin VH usage and VDJ combinations in the human response to Haemophilus influen$z a e$ type b capsular polysaccharide. Nucleotide sequences of monospecific antiHaemophilus antibodies and polyspecific antibodies cross-reacting with self antigens. J. Clin. Invest. 91:2734-2743.

23. Pirofski, L., R. Lui, M. DeShaw, A.B. Kressel, and Z. Zhong. 1995. Analysis of human monoclonal antibodies elicited by vaccination with a Cryptococcus neoformans glucoronoxylomannan capsular polysaccharide vaccine. Infect. Immun. 63:3005-3014.

24. Rioux, J.D., M. Ohlin, C.A.K. Borrebaeck, and M.M. Newkirk. 1995. Molecular characterization of human monoclonal antibodies specific for the human cytomegalovirus: relationship of variable region sequence to antigen specificity and rheumatoid factor-associated idiotype expression. Immunol. Infect. Dis. (Lond.). 5:43-52.

25. Hillson, J., N.S. Karr, I.R. Oppliger, M. Mannik, and E.H. Sasso. 1993. The structural basis of germline-encoded $\mathrm{V}_{\mathrm{H}} 3$ immunoglobulin binding to staphylococcal protein A. J. Exp. Med. 178:331-336.

26. Rioux, J.D., J. Rauch, L. Silvestri, and M.M. Newkirk. 1994. A human rheumatoid factor $\mathrm{C} 304$ shares $\mathrm{V}_{\mathrm{H}}$ and $\mathrm{V}_{\mathrm{L}}$ gene usage with antibodies specific for human viral pathogens. Scand. J. Immunol. 40:350-354.

27. Pilkington, G.R., L. Duan, M. Zhu, W. Keil, and R.J. Pomerantz. 1996. Recombinant human Fab antibody fragments to HIV-1 Rev and Tat regulatory proteins: direct selection from a combinatorial phage display library. Mol. Immunol. 33:439-450.

28. Andris, J.S., P.H. Ehrlich, L. Ostberg, and J.D. Capra. 1992. Probing the human antibody repertoire to exogenous antigens. Characterization of the $\mathrm{H}$ and $\mathrm{L}$ chain $\mathrm{V}$ region gene segments from anti-hepatitis $\mathrm{B}$ virus antibodies. $J$. Immunol. 149:4053-4059.

29. Andris, J.S., S. Johnson, S. Zolla-Pazner, and J.D. Capra. 1991. Molecular characterization of five human anti-human immunodeficiency virus type I antibody heavy chains reveals extensive somatic mutation typical of an antigendriven immune response. Proc. Natl. Acad. Sci. USA. 88:7783-7787.

30. Betz, A.G., M.S. Neuberger, and C. Milstein. 1993. Discriminating intrinsic and antigen-selected mutational hotspots in immunological $\mathrm{V}$ genes. Immunol. Today. 14:405-411.

31. Rogozin, I.B., and N.A. Kolchanov. 1992. Somatic hypermutagenesis in immunoglobulin genes. II. Influence of neighbouring base sequences on mutagenesis. Biochem. Biophys. Acta. 1171:11-18.

32. Smith, D.S., G. Creadon, P.K. Jena, J.P. Portanova, B.L. Kotzin, and L.J. Wysocki. 1996. Di- and trinucleotide target preferences of somatic mutagenesis in normal and autoreactive B cells. J. Immunol. 156:2642-2652.

33. Kieber-Emmons, T., J.M. von Feldt, A.P. Godillot, D. McCallus, V. Srikantan, D.B. Weiner, and W.V. Williams. 1994. Isolated $V_{H} 4^{+}$heavy chain variable regions bind DNA. Characterization of a recombinant antibody heavy chain library derived from patient(s) with active SLE. Lupus. 3:379-392.

34. Brezinschek, H.P., R.I. Brezinschek, and P.E. Lipsky. 1995. Analysis of heavy chain repertoire of human peripheral B cells using single-cell polymerase chain reaction. J. Immunol. 155:190-202.

35. Manheimer-Lory, A., R. Monhian, A. Splaver, B. Gaynor, and B. Diamond. 1995. Analysis of the $\mathrm{V}_{k} I$ family: germline genes from an SLE patient and expressed autoantibodies. Autoimmunity. 20:259-265.

36. Bensimon, C., P. Chastagner, and M. Zouali. 1994. Human anti-DNA autoantibodies undergo essentially primary $\mathrm{V}_{\mathrm{k}}$ gene rearrangements. $E M B O$ (Eur. Mol. Biol. Organ.) J. 13:2951-2962.

37. Suzuki, N., T. Harada, S. Mihara, and T. Sakane. 1996. Characterization of a germline $\mathrm{V}_{\kappa}$ gene encoding cationic anti-DNA antibody and role of receptor editing for development of the autoantibody in patients with systemic lupus erythematosus. J. Clin. Invest. 98:1843-1850.

38. Rioux, J.D., E. Zdarsky, M.M. Newkirk, and J. Rauch. 1995. Anti-DNA and anti-platelet specificities of SLE-derived autoantibodies: evidence for $\mathrm{CDR} 2{ }_{\mathrm{H}}$ mutations and CDR3 motifs. Mol. Immunol. 32:683-696.

39. Radic, M.Z., and M. Weigert. 1994. Genetic and structural evidence for antigen selection of anti-DNA antibodies. Annu. Rev. Immunol. 12:487-520.

40. Watanabe-Fukunaga, R., C.I. Brannan, N.G. Copeland, N.A. Jenkins, and S. Nagata. 1992. Lymphoproliferation disorder in mice explained by defects in Fas antigen that mediates apoptosis. Nature. 356:314-317.

41. Kuo, P., A. Alban, D. Gebhard, and B. Diamond. 1997. Overexpression of bcl-2 alters usage of mutational hot spots in germinal center B cells. Mol. Immunol. In press.

42. Mazel, S., D. Burtrum, and H.T. Petrie. 1996. Regulation of cell division cycle progression by bcl-2 expression: a potential mechanism for inhibition of programmed cell death. J. Exp. Med. 183:2219-2226.

43. O'Reilly, L.A., D.C.S. Huang, and A. Strasser. 1996. The cell death inhibitor Bcl-2 and its homologues influence control of cell cycle entry. $E M B O$ (Eur. Mol. Biol. Organ.) J. 15:6979-6990.

44. Gatenby, P.A., and M. Irvine. 1994. The bcl-2 protooncogene is overexpressed in systemic lupus erythematosus. J. Autoimmun. 7:623-631.

45. Rose, L.M., D.S. Latchman, and D.A. Isenberg. 1995. Bcl-2 expression is unaltered in unfractionated peripheral blood mononuclear cells in patients with systempic lupus erythematosus. Br. J. Rheumatol. 34:316-320. 